\title{
Higher Education Reforms and the Academic Profession from a Comparative Perspective
}

\author{
ARImoto, Akira*
}

In the $21^{\text {st }}$ century, when the universalization of higher education demands diversified students to be more involved in study and rather than in learning, the ideal of scholarship is expected to transform toward both teaching orientation and study orientation, with a focus on the teaching and study process in the classrooms with a result of being a research, teaching and study nexus ( $R-T-S$ nexus). In reality, however, it is apparent that the scholarship of research orientation persists throughout the world. This paper attempts to shed light on the given theme by making analysis of the results gained from three international surveys on the academic profession.

Higher education is defined by the mutual interaction among several important factors, including social change, knowledge development, the national government's higher education policy, and the academic profession's identity and initiative in the process of reacting to the effects of these factors. In this picture, the priority of reform converges to the teaching and study process in which academics' teaching ability and students' study ability are focal.

The Humboldtian model is useful, not only for students at the stage of elite higher education in the second age, but also for the counterparts at the stage of universalization in the third age, although it needs to be modified so as to be suitable to the situation at the universal stage of higher education development.

Comparison between academics' preferences in teaching and research orientations by country in the CAP survey reveals that convergence on the research orientation has increased, at least in advanced countries. The universalization of higher education will need more of a teaching orientation among academics worldwide, to support students'study and so the current trend toward a research orientation must necessarily be confronted in the context of R-T-S nexus in many countries, especially in Japan.

Keywords: academic profession; R-T-S nexus; higher education reform; universalization; knowledge-based society

* Kurashiki Sakuyo University

e-mail: arimotoakira@gmail.com 


\section{Introduction}

Academics have been expected to be the main actors in conducting teaching for many years since the institutionalization of the medieval university, or the pre-modern university. Since the appearance of modern university, with the intense development of the research function, academics possessing the traditional identity of teachers formed at the pre-modern university were forced to shift themselves to conform to the new identity of the academic profession possessing the dual role of researchers and teachers at the same time. However, after the first age of the medieval university and the second age of the modern university, we are now in an emerging third age, and the academic profession is expected to transform to another phase, when the academic profession is expected to pay more attention to students as learners, particularly in the undergraduate courses of the university.

In the $21^{\text {st }}$ century, when the universalization of higher education demands diversified students to be more involved in study and rather than in learning, the ideal of scholarship is expected to transform toward both teaching orientation and study orientation, with a focus on the teaching and study process in the classrooms with a result of being a research, teaching and study nexus (R-T-S nexus). In reality, however, it is apparent that the scholarship of research orientation persists throughout the world according to some international surveys on the academic profession.

Based on these considerations, this paper attempts to shed light on the given theme by making analysis of the results gained from three international surveys of the academic profession: the Carnegie survey conducted in 1992, the CAP (Changing Academic Profession) survey in 2007and the APA (Academic Profession in Asia) survey in 2012.

\section{Necessity of Higher Education Reforms and the Role of the Academic Profes- sion}

Higher education today is defined by mutual interaction among several important factors, including social change, knowledge development, the national government's higher education policy, and the academic profession's identity and initiative in the process of reacting to the effects of these factors. Accordingly, the research framework deals with relationships between social reform and the academic profession with a focus on a vision of the academic profession in the changing relationship between society, the government, the university, and knowledge as follows (Figure 1).

i. Effects of social change (at the level of international, national and regional society) on the academic profession (arrow a) and functions of the academic profession on social change (arrow b); ii. Effects of government (national higher education policy) on the academic profession (arrow c) and functions of the academic profession (arrow d); iii. Effects of knowledge (its differentiation, integration, reconstruction, etc.) on the academic profession (arrow e) and functions of the academic profession in relation to knowledge through academic work (arrow f); iv. Effects of the university (its system, sector, section, hierarchy, etc.) on the academic profession (arrow g) and functions of the academic profession in relation to the university (arrow $\mathrm{h}$ ). We study the structure and function of the university on the basis of the perspectives of $a, b, c$, $\mathrm{d}, \mathrm{e}, \mathrm{f}, \mathrm{g}$ and $\mathrm{h}$. In particular, attention will be paid to the institutionalization of the academic 


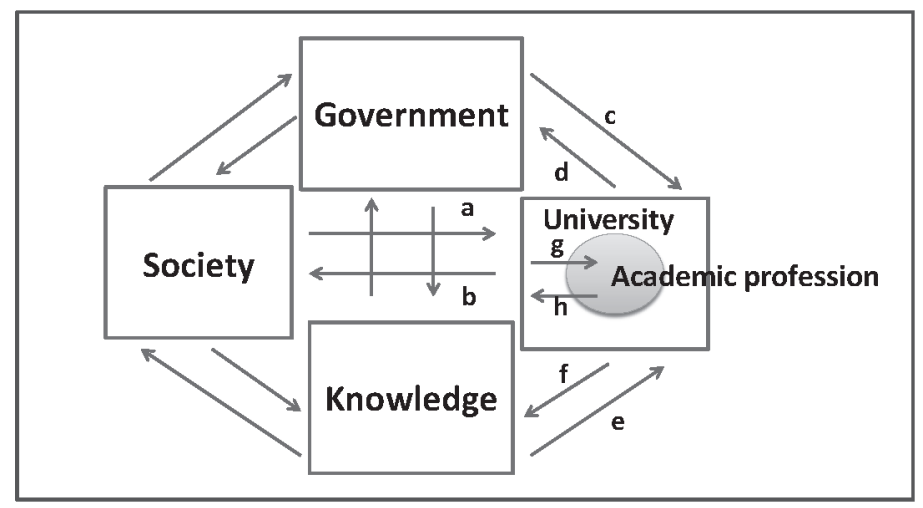

Figure 1 Environment changes of the academic profession

profession from academics, and the academic profession's relationship to functions of his/her academic discipline (research and teaching orientation, academic productivity, etc.).

Based on the previous description, four effects and functions between the academic profession and society, knowledge, government and university, respectively, will be explained in more detail in the following part.

First, the factor of social change has a great effect on higher education reforms, because the university is socially affected by social conditions, while at the same time it contributes to society by social functions such as research, teaching and service.

Various factors related to social change such as globalization, knowledge society, marketization, lifelong education and learning, and the declining birth rate and increasing aging population cause manifest and latent effects on higher education reforms. On the other hand, various factors related to social function such as research, teaching and service make a valuable contribution to social development (Arimoto, ed., 2013b). Research and teaching between them constitute two important vehicles in academic work so that the lack of either of them would surely reduce the university's social meaning. In this context, it is the university's teaching reforms that are related directly to higher education reforms. If university teaching reform is thought to be inevitable as a social function of the university, it is natural that university teaching reform is situated at the core of higher education reforms.

Second, knowledge has a great weight in higher education reforms, because research and teaching that exist at the core of academic work are functions of the basis of knowledge as material (Clark 1983). Research is the discovery of knowledge and teaching is the dissemination of knowledge. These two functions make a contribution to social development through contributions to the academic community by discovering knowledge and also by training and teaching manpower useful for social development.

The concept of academic work is connected to that of academic productivity, because the latter is an indicator of academics' involvement in enhancement and the outcome of the former, theoretically consisting of research productivity, teaching productivity and service productivity. Among these, research productivity and teaching productivity are considered to be most important in terms of making a contribution to social development, since these are two vehicles of academic work, as was previously noted.

Academic productivity, especially research productivity, is a concept derived from that of "scientific productivity", originally proposed by Robert K. Merton as a technical term in his 
sociology of science. This concept is important in measuring outcomes of academics' commitment to research and teaching in academic work, because the main role of the academic research enterprise in the academic community is to raise academic productivity, while the main role of the research enterprise in the scientific community is to raise scientific productivity (Merton, 1973; Shinbori, 1973; Arimoto, 1978, 1981, 2007, 2011). The concept of academic productivity is increasingly adaptable to explanation for various phenomena such as Centers of Learning, COE (Centers of Excellence) and university rankings (Arimoto, ed., 1996; Ben-David, 1977; Shin, Toutkoushian and Teichler, eds., 2011; NISTEP, 2013). This fact is evidence of the weight of research paradigm that has been substantially and overwhelmingly stressed in academic work in the modern university.

Third, through a national higher education policy the national government has a mechanism to have an effect on higher education reforms. Without establishing a clear vision of the university to advance on the basis of knowledge development as well as social change, the university cannot contribute to social development because it necessarily loses the compass that indicates where to go in future. Higher education policy carries significant weight in determining the future direction of a given country in terms of its prosperity or decline.

In fact, almost all national governments today seem to expect their own universities to be a core of the knowledge-based society as well as centers of scholarship, proclaiming enhancement of their own prestige throughout the world by raising universities' international competitiveness in research and teaching. They usually try to invest of substantial resources in specific universities, especially research universities, with high academic productivity, by using a policy of selection and concentration (Arimoto, ed., 2011). All countries in the world are apt to proclaim the advancement and elaboration of higher education policy so as to make higher education stronger and much more competitive in the academic marketplace of the world with respect to its quality as well as its quantity. On the basis of this kind of attempt, they are increasingly involved in higher education reforms.

In the case of Japan, for example, the main national higher education policies have been issued by the University Council (UC), as well as by the Central Council of Education (CCE), since 1991 when UC issued an important proposal for higher education reforms (UC, 1991). Other main reports with overall designs for the future of higher education in Japan over the mid- to long-term were issued by UC in 1998, followed by CCE in 2005, 2008 and 2012 (UC, 1998; CCE, 2005, 2008, 2012).

These attempted to construct a series of important higher education policies in connection with higher education reforms. In particular, a proposal for university education reforms in 2012, which was a development of the content of the report in 2008, is worthy of notice, because it made clear the direction of teaching reforms for the future. It attempted to underline students' active study in the teaching and study process inside and outside the classroom. The teaching and study process is at the core of higher education at the level of the university so that academics' teaching reforms are inevitable for its realization. This proposal seems to reveal that the higher education policy issued this time with a focus on teaching reforms is more advanced than previously issued ones.

Fourth, the reaction of the academic profession, as well as the university, against the external environment regarding higher education reforms is likely to be the most important factor among the many forces at work. The university is compelled to respond either conservatively or progressively to a series of pressures from social change, knowledge development, 
and national higher education policy, because it cannot escape the fact that university development is necessarily affected by its external environments to a considerable degree. It is also unavoidable that reactions of various kinds of stakeholders inside the university, such as academic staff, non-academic staff and students, cannot be ignored. In particular the pattern of response on the part of academics is worthy of attention because it has substantial influence on the concrete pursuit of the university ideal and vision for the future. In other words, their initiative is important in higher education reforms, not only in their ideal visions but also in their real pursuit. In fact, if we think that a central goal of the current higher education reforms is reform of the teaching and study process in universities, how to enhance both academics' teaching ability and students' study ability is the most important problem to solve, and it is academics who are thought to be the main actors to bring about a successful outcome.

As described previously, higher education reforms today are defined mainly by social change, knowledge development, national higher education policy, and reactions by the university and the academic profession, so that the priority in reforms is likely to convergence to the teaching and study processes in which academics' teaching ability and students' study ability is focal. This means that students are asked to shift from leaning orientation to an active study orientation and at the same time academics are asked to shift from a research orientation to an active teaching orientation to the extent that they will shift to be involved in the research, teaching and study nexus (R-T-S nexus). In other words, they are required to transform from the status of academic staff to that of the academic profession.

\section{Role of the Academic Profession in the Third Age}

\section{(1) Possibility of a Humboldtian model}

Teaching constituted a main part of academic work in the university for several centuries from the medieval university to the modern university, where sciences and research were institutionalized systematically in the university. The ideal feature of the old type of academics who took part in teaching as teachers of students was "good teacher" as shown in the expression of "pastoral care of undergraduates," and also "learned teacher" and "scholar and teacher". They were expected to take care of students "in loco parentis" and through an "osmosis process" (Halsey and Trow, 1971; Ross, 1976; Arimoto, 1981, p. 58).

At this time, an academic career was simple, with teaching involvement in many disciplines without research involvement in a specific discipline. This type of academic career lasted for about six centuries through the middle age of the university before the beginning of the modern university, in which the system for training students in graduate schools for the academic career was institutionalized.

The modern university which institutionalized science and research functions in academic work, together with an academic career with research involvement in addition to teaching involvement, emerged for the first time in the history of higher education owing to the institutionalization of the graduate school as preparation for the academic career (Brubacher and Rudy, 1968, p. 183; Light, 1974).

In the modern higher education system, the function of knowledge expanded and diversified greatly so that the graduate school was established as the place of division of labor, separate from but cooperating with the undergraduate tier (Clark, 1983). However, the institution- 
alization of the graduate tier promoted a research paradigm with hypertrophy of research-ism. Accordingly, it was naturally expected that academics would integrate research and teaching without separating them. In fact, Earnest Boyer discussed the importance of teaching in the prevailing research paradigm in his book, Scholarship Reconsidered, published in 1990, which the author of this paper translated into Japanese (Boyer, 1990). This fact shows integration between research and teaching had hardly been achieved in 1990 after many years have passed since the modern university was institutionalized.

In spite of this fact, however, it is true that modern university was expected from its beginning to integrate teaching, which was institutionalized in the university of the Middle Ages, and research which was institutionalized newly in the modern university. Actually, Wilhelm von Humboldt proposed an integration of teaching and research as a useful vision for the modern university (Von Humboldt, 1910; Clark, ed., 1993; Clark, 1995). "His idea of combining both teaching and research in one institution that guided him in establishing the University of Berlin in 1810 (today's Humboldt University) and the structures he created for this institution would become the model for universities not only in Germany but also in most Western countries" (Stanford Encyclopedia of Philosophy, 2012).

\section{(2) The usefulness of the Humboldtian model in the third age}

Of course, there are some critics of this vision. First, as Anderson pointed out, there is not necessarily any positive discussion about the Humboldtian model as an initiator and impulse for modern universities. "The view that the adoption of the Humboldtian model is the key to understanding the evolution of the modern University in Europe and America has been severely modified by recent university historians" (Anderson, 2010, p. 141).

Second, there is a critique of this model which makes the point that it is appropriate for academics at the elite stage of higher education but it is not appropriate for today's academics. "Ways of thinking that define academics as researchers and looks upon expression of research outcome as the highest teaching is considered to be formed on the assumption of teaching for elite students and has less meaning to today in the $21^{\text {st }}$ century" (CCE, 2004). It is true to say this to a considerable degree due to quite a few differences in student ability at the two stages. Elite students could study well without integrated research and teaching. However, academics' research ability in integrated research and teaching is needed more and more to teach students with diverse abilities at the universalization stage of higher education.

The knowledge society today is different from a traditional knowledge society within the academic domain, where elite students were already expected to study instead of leaning. In the present knowledge society, which is without borders between academia and society, students are expected to change from a state of learning to that of study, although far behind the elite students, so as to realize their abilities such as creativity, problem solving and critical thinking. It is likely to be necessary for these students to integrate research and study in order to realize such abilities, while academics are expected to integrate research and teaching so as to enhance student's active study in the teaching and study process. In this context, integration of research and teaching is needed in academics and also integration between research and study is needed in students in the knowledge-based society.

Considering these circumstances, we have to think how to build a vision of the future university with integrated research and teaching in the increasing knowledge-based society as well as with the universalization of higher education. It will not be an oversimplification to 
suggest that the scale of the teaching function will increase in importance relative to that of the research function, because both functions have to work intimately together in an academic institution corresponding to the knowledge-based society as well as the universalization of higher education.

At the same time, in addition to reconsideration of the relationship between research and teaching, reconsideration is needed of the teaching and study process to meet increasing super-diversification of students' needs and qualities in the age of universalization of higher education. Supporting students' study becomes necessary to the extent that higher education cannot be pursued adequately without guaranteeing an integration of research, teaching, and study (Humboldt, 1910; Nicolls, 2005; Arimoto, 2013a, 2013b). In this context, the Humbordtian model is useful, not only for students at the stage of the elite or second age, but also for the counterparts at the stage of universalization in the third age, although it needs to be adapted so as to meet the situation at the universal stage of higher education development.

Third, It is undeniable that the German model, based on Humboldtian ideal, is worthy of note, even though there are some competing models, such as the British model, the French model and the American model, in an international perspective. Therefore, it is likely to be a basic problem whether the Humoldtian ideal, in addition to forming the core of the German university model had actually been implemented in modern universities and colleges worldwide over the two centuries since it was first proposed. (Cf. Ushiogi, 2008). We will discuss this matter later.

\section{Convergence on a Research Orientation in Advanced Countries According to the 2007 CAP Survey}

If this kind of scholarship is expected to prevail in all universities of the world, academics must be involved in both research and teaching orientations at the first stage and R-T-S nexus in the second stage. What is occurring in the real situation related to this matter in the academic profession? In this regard, it is interesting for us to pay attention to the results of a current international survey on the academic profession worldwide.

The Carnegie International Survey of the Academic Profession was conducted in 1992 by 14 participating countries (in reality, 13 countries, Australia, Brazil, Chile, Germany, Israel, Japan, Korea[Republic of Korea], the Netherlands, Mexico, Russia, Sweden, the U.K., the U.S., and the region of Hong Kong) (Altbach, ed., 1996). Based on this survey, an analysis of academics' orientation to research and teaching identified three types: a research orientation; a research and teaching orientation; and a teaching orientation (Arimoto and Ehara, eds., 1996). The first type, designated a German model, stresses research more than teaching, and is found in countries such as the Netherlands, Japan, Germany, Sweden, and Korea. The second type, designated an Anglo-Saxon model, stresses research and teaching evenly, and occurred in countries such as the U.K., the U.S., Australia, and Hong Kong. The third type, designated a Latin American model, stresses teaching more than research, and is found in countries such as Argentina, Chile, and Brazil.

The Anglo-Saxon model seems to approach the Humboldtian ideal most closely in the sense that it seems to conform to the pattern of integrated research and teaching. On the other hand, the German model, with its strong emphasis on research, tends to put stress on academic 
staff as researchers and too little to students as learners. In contrast, the Latin American model puts more weight on teaching and the students and less on research and the academic staff.

The Changing Academic Profession (CAP) survey took place in 2007 with the participation of nineteen countries (in reality, eighteen countries, Argentina, Australia, Brazil, Canada, China, Finland, Germany, Italy, Japan, Korea, Malaysia, Mexico, the Netherlands, Norway, Portugal, South Africa, the U.K., and the U.S., and one region, Hong Kong)(Arimoto, ed., 2008, 2010; Shin, Arimoto, Cummings and Teichler, eds. 2013). There are two groups consisting of the advanced countries and the emerging countries. The former consists of thirteen countries, Canada, the U.S., Finland, Germany, Italy, the Netherlands, Norway, Portugal, the U.K., Australia, Japan, Korea, and Hong Kong, while the latter consists of six countries, Argentina, Brazil, Mexico, South Africa, China, and Malaysia.

"Research orientation is highest in Norway (83\%), followed by Italy, Japan, Australia, and Korea, while teaching orientation is highest in Mexico (57\%), and followed by the U.S., South Africa, China, and Malaysia. The total average proportion for research orientation is $60 \%$ and that for teaching orientation is $40 \%$. Research orientation is higher than teaching orientation by $20 \%$ among all participating countries. If we compare this result with that of the seven countries of Brazil, Hong Kong, Japan, Korea, Mexico, the UK, and the U.S. in the Carnegie survey, it provides useful data for a comparison of the trend between the two surveys, with the former at $51 \%$ and the latter at $60 \%$ (Arimoto, 2011, p. 8). It is interesting to note that the academic profession reinforced its research orientation by almost $10 \%$ within 15 years after 1992." (Arimoto, 2013b, p. 24)

"Focusing at the country level, it can be inferred that a research orientation is: a. Cleary dominating (more than 65\%) among the academics surveyed by the CAP survey in Norway (83\%), Italy (77\%), Japan (71\%), Australia (69\%), Canada and Korea (68\% each) and the UK $(67 \%)$; b. Somewhat dominating (51-65\%) in Finland (65\%), Germany and Hong Kong (63\%), the Netherlands (56\%), Portugal (53\%) and Argentina (51\%).; c. Only true for the minority of academics (less than $50 \%$ of the respondents) in Brazil (48\%), Malaysia (47\%), South Africa (46\%), China and the U.S. (each 44\%) and Mexico (43\%)" (Arimoto, 2013a, p. 121)

"Among the ten countries participating in both surveys, only Japan is classified at both stages as a strong research orientation. Germany and the Netherlands have moved from a strong research orientation towards more of balance between research and teaching, while in reverse, Korea, Australia and the UK have moved from a balance towards a strong research orientation. Hong Kong has remained unchanged in the middle position, and Mexico, the U.S. and Brazil have remained unchanged countries with minority emphasis on research." (Ibd., p. 122)

On the other hand, recognizing such convergence on research in many countries, especially in advanced countries, research orientation seems to be the predominant trend that has occurred in the past fifteen years. In this trend, a greater teaching orientation (teaching $>$ research) is recognized in the U.S., Brazil, Mexico, South Africa, China, and Malaysia. Only the U.S. belongs to this category from the advanced country group, while all countries except Argentina belong to this category in the emerging country group. 


\section{Compatibility of Research and Teaching}

\section{(1) General trend: difficulty in making compatible is highest in Japan}

Academics' emphasis on a research orientation was strengthened during the past fifteen years in many countries, especially in advanced countries. In this context, it seems to be reasonable for us to anticipate that the trend of differentiation between research and teaching is gradually increasing at the expense of any nexus between them.

According to the 2007 CAP survey, the proportion of academics overall who agreed with the statement that, "Teaching and research are hardly compatible with each other" is $23 \%$ : specifically, 25\% in advanced countries and 20\% in emerging countries (Arimoto, 2013a, p.129). The proportion of "hardly compatible" is highest in Japan (51\%), followed by China (42\%), Finland (38\%), Germany (33\%), Malaysia (30\%), and Australia (28\%). Conversely, in some countries few academics agreed with the statement: Argentina (6\%), Brazil (7\%), Korea, Mexico (each 11\%), the U.S. (12\%), Norway and Italy (each 14\%). That these countries reject incompatibility means they agree with the idea of compatibility to a great extent. It is interesting that Latin American countries such as Argentina, Brazil, and Mexico belong to this category.

\section{(2) Research and teaching orientation and compatibility}

A conbination of two factors is possible: the relationship between research orientation (or teaching orientation) and the compatibility of teaching and research by country. There are four types consisting of two research orientation types (Research Type 1 and 2) and two teaching orientation types (Teaching Type 1 and 2).

Research Typel $(++)$ : The first type of high research orientation and high compatibility consists of two countries, Korea and Italy. Research Type 2(+-): The second type of high research orientation and low compatibility consists of six countries, Japan, Finland, Germany, Australia, Portugal, and Hong Kong. Teaching type $1(-+)$ : The third type of low research orientation (or high teaching orientation) and high compatibility consists of three countries, Brazil, the U.S., and Mexico. Teaching type $2(--)$ : The fourth type of low research orientation (or high teaching orientation) and low compatibility consist of three countries, China, Malaysia, and South Africa.

Based on this classification, it can be said that the countries with a high teaching orientation experience greater compatibility between research and teaching than the countries with high research orientation, although differences between the two groups are small. As far as this trend is concerned, it seems that compatibility between research and teaching is becoming more difficult at the time when research orientation is increasing among academics in the world.

At the same time, as far as the Japanese academic profession is concerned, we can indicate three problematic points as follows: first, low teaching orientation in spite of high research orientation; second, low compatibility between research and teaching; and third, declining research productivity and teaching productivity as discussed below. 


\section{Declining Research Productivity and Teaching Productivity}

\section{(1) Research productivity}

Throughout the world, an increasingly knowledge-based economy has promoted unification in a common academic marketplace worldwide, where academia has been compelled to change from a "knowledge community", in which Merton's ethos of CUDOS worked, to a "knowledge enterprise", in which traditional ethos is losing ground (Merton, 1973; Arimoto, 1987). The international trend of strengthening research orientation is likely to proceed in accordance with this kind of change in academia. In addition, the reward system is working to reinforce the research paradigm more than the teaching paradigm. For example, eminent academics with high research productivity usually have a high reputation in connection to upward mobility in their academic career.

Who are the eminent academics? In the sociology of science, Cole and Cole discuss the relationship between the "quantity" and "quality" of the research papers produced by 120 physicists (Coke and Cole, 1967). Based on the combination of "quantity" and "quality", they generated four types of physicists: Type I $(++)$ is the prolific physicist who produces an abundance of papers which tend also to be fruitful (ie., often used by others in the field); Type II $(+-)$ is the mass producer who publishes a relatively large number of papers of little consequence; Type III $(-+)$ is the perfectionist who publishes comparatively little but what they do publish has a considerable impact on the field; and Type IV (--) is silent physicist. The percentage of these four types are as follows: Type I (33\%); Type II (12\%); Type III (18\%); Type IV (37\%).

It is interesting there are as many as $37 \%$ of silent physicists. If we use this typology, a category of eminent academics is perhaps related to two types, Type I and Type III, which contain a total percentage of $51 \%$. (Ibid., p. 381). This is a case study of 120 physicists and probably there are various kinds of results we might get if we made case studies in the fields of sciences other than physics (Arimoto, 1994).

Reconstruction of knowledge has proceeded together with a rationalization of academic organization so that phenomena such as head-hunting of eminent academics, brain drain and gain, stratification between haves and have-nots, and the Mathew effect become familiar occurrences. In fact, observing world university ranking, we have to accept that research universities are usually situated at the top of the ranking order. For example, as the ranking in the London Times' University Ranking 2010 indicates, all the universities ranked in its top ten are research universities, Harvard, Caltech, MIT, Stanford, Princeton, UCB, and Yale in the U.S. and Cambridge, Oxford, and Imperial College London in the U.K. (London Times, 2008; Thomson Reuters, 2010).

These eminent academics are apt to be concentrated in leading research universities in Japan as well as in other parts of the world. Leading universities recruiting many eminent academics with high research productivity will be ranked in higher positions in the ranking order. In this context, only two Japanese institutions were ranked in the top 100 in the world university ranking conducted by the London Times in 2010. More institutions are expected to be ranked by raising academic productivity. Nevertheless, research productivity of Japanese academics is showing a decline recently.

According to the statistical data of Kagaku Gijutsu Seisaku Kenkyusho (NISTEP: National Institute of Science and Technology Policy, Japan) on the basis of Thomson Reuter's Web of 
Science, we can recognize the total number of articles in the main journals published worldwide (NISTEP, 2013, p. 1). Japan's average number of articles published in 1999-2001 was 73,844 and the ranking share in the total of published articles in the world was second, while those in 2009-2011 was 76,149 and the ranking share was fifth. The top ten countries were the U.S., China, Germany, the U.K., Japan, France, Italy, Canada, Spain, and India. Japan' position decreased, though the number of articles increased. The average ratio of Increase is $48 \%$ in the world, while it is only $3 \%$ in Japan. In addition, the number of article citations decreased from fourth to seventh in the same period. It is remarkable that as far as the number of articles and article citations is concerned, Japan fell from the second place in 2001 to the fifth and seventh place in 2011.

Of course, there are many problems about such rankings at the institution level as well as the country level in terms of the technologies implicit in them, including the English language, which seems to give a great advantage to academics in Anglo-Saxon countries (Shin, Toutkoushian, and Teichler, eds., 2011). The effects of ranking are both positive and negative and also both functional and dysfunctional. Based on this, however, it is remarkable that the Japanese type of academic profession characterized by a strong research orientation and low compatibility between research and teaching has not worked well thus far in such ranking in the world. The negative and dysfunctional sides are related to phenomena including "differentiation of society between haves and have-nots, separation between research universities and non-research universities, the increase of the research paradigm and decline of the teaching orientation," etc. (Arimoto, 2011, p. 241.)

The fact that research productivity is declining means the brakes are put on the long tradition of research orientation. However, we must pay attention to a great deal of stagnation with respect to teaching productivity, because teaching is a weak point for the academics as well as academia in Japan for a long time and also it will be an important problem to be pursued intensively. In this context, data available from the international survey of APA clearly suggests that Japanese academics' improvement of teaching is facing serious conditions.

\section{(2) Teaching productivity}

As for the second problem, teaching orientation has not connected well with teaching improvement, or teaching productivity. Against the strong trend of research orientation, Japanese higher education policy has intentionally stressed academics' teaching orientation since UC's proposal in 1991 previously mentioned, although it had ceaselessly stressed a research orientation for many years since Meiji Restoration before the war. However, as shown clearly in the trends of international surveys discussed previously, it is obvious that a series of higher education policies have not been successful at all until today, perhaps because the national government supported a strong research orientation policy before 1991 when UC introduced a teaching orientation, probably for the first time in higher education history in Japan (UC, 1991).

It is interesting to note the outcomes of the APA survey conducted in 2012, because only Japanese academics among the six Asian countries showed low scores on to many questions related to higher education reforms over the previous five years. Concretely, Japanese academics responded negatively to the question about "Improvement of the quality of educational activities over the past five years" in terms of a low response rate to "much improved", with the lowest ratio of $5.8 \%$ against a total average ratio of $14.9 \%$ (Arimoto, Daizen, Kimoto, and Huang, 2013). Responses to the question about "The quality of the students currently 
enrolled" by Asian countries with "good" were as low as $10.6 \%$ compared with as high as $48.7 \%$ for the total average. Response to "The training for your role as teacher" had a response rate for "much improved" of as low as $41.2 \%$ compared with $64.0 \%$ for the total average. Further, response to "The existence of adequate training courses for enhancing teaching quality" had a response rate for "agree" of $27.3 \%$ against $43.9 \%$ for the total average. Training for the teacher's role and adequate training courses for teaching quality have not been prepared and the quality of students has decreased. Japanese academics are likely to be confronted with the worst conditions among the six Asian countries participating in the APA survey.

The results seem to be problematic as they show the lowest ratios for all questions. As far as these results are concerned, Japan's ability to deal with "Improvement of the quality of educational activities over the past five years" is likely to be the lowest, although it has tried to enhance teaching improvement among academics, as well as universities and colleges, by a series of national policies of higher education reforms since 1991 when UC proposed the systematic improvement of teaching.

\section{Conclusion}

First, higher education is defined by the mutual interaction among several important factors, including social change, knowledge development, the national government's higher education policy, and the academic profession's identity and initiative in the process of reacting to the effects of these factors. Based on this picture, the priority of reform converges to the teaching and study process in which academics' teaching ability and students' study ability are focal. Students are asked to shift from a leaning orientation to a study orientation, while academics are asked to shift from a research orientation to a teaching orientation to the extent that they will shift to be involved in the research, teaching and study nexus (R-T-S nexus).

Second, the Humboldtian model is useful, not only for students at the stage of elite higher education in the second age, but also for the counterparts at the stage of universalization in the third age, although it needs to be modified so as to be suitable to the situation at the universal stage of higher education development. It was generally possible for academics to teach students in the second age, who were homogeneous in their abilities using most advanced research results but it is generally difficult for them to teach students in the third age, who are diversified and heterogeneous in their abilities using same kinds of advanced research results. In order to overcome this gap, a range of devices are needed to introduce into the teaching and study process. Active study is encouraged by introducing devices such as study of before and after class, discussion and debate, rubric, office hours, teaching and learning portfolios, field study, study abroad, etc.

Third, comparison between academics' preferences in teaching and research orientations by country in the CAP survey reveals that convergence on the research orientation has increased, at least in advanced countries. It is said that the compatibility of research and teaching is becoming more difficult at a time when the research orientation is increasing among academics around the world. As far as the Japanese academic profession is concerned, we can indicate three problematic points as follows: First, a low teaching orientation in spite of a high research orientation; Second, low compatibility of research and teaching; Third, declining research productivity and teaching productivity. 
Fourth, the universalization of higher education will need more of a teaching orientation among academics worldwide, to support students' study and so the current trend toward a research orientation must necessarily be confronted in the context of R-T-S nexus in many countries, especially in Japan. Accordingly, a tentative conclusion of this paper is that this situation needs to be improved, as far as that is possible.

\section{References}

Altbach, P.G. (Ed.) (1996). The international academic profession: Portraits of fourteen countries. Princeton: Carnegie Foundation for the Advancement of Teaching.

Anderson, R. (2010). University history teaching and the Humboldtian model in Scotland, 1858-1914, History of Universities, Volume XXV/1.Oxford: Oxford University Press, pp 138-184.

Arimoto, A. (1981). Daigakujin no shakaigaku (Sociology of academics). Tokyo: Gakubunsha Publishing Co.

Arimoto, A. (1987). Merton no kagakushakaigaku: Paradaimu no keisei to tenkai (Sociology of science in Robert K. Merton: Formation and development of its Paradigm). Tokyo: Fukumura Publishing Co.

Arimoto, A. (1994). Senmon bunya to gakumontekiseisansei: Beikokukenkyudaigaku no jirei(Academic discipline and academic productivity: Case study on research universities in the U.S.). Daigaku Ronshu, No. 23, pp. 27-47. Hiroshima: RIHE, Hiroshima University.

Arimoto, A. [Ed.] (1996). Gakumonchushinchi no kenkyu (Study on the Centers of Learning). Tokyo: Toshindo Publishing Co.

Arimoto, A. (2007). Remarks on the relationship between knowledge functions and the role of the university. In Sverker Sorlin \& Hebe Vessuri, eds., Knowledge society vs. knowledge economy: Knowledge, power, and politics. New York: Palgrave Macmillan, pp. 175-197.

Arimoto, A. (2008). International Implications of the Changing Academic Profession in Japan, Report of the International Conference on the Changing Academic Profession Project, 2008, pp. 1-31. Hiroshima: RIHE, Hiroshima University.

Arimoto, A. [Ed.] (2010). Henbousurusekai no daigakukyoujushoku (The changing academic profession in the world). Tokyo: Tamagawa University Press.

Arimoto, A. (2011). Reaction to Academic Ranking: Knowledge Production, Faculty productivity from an International Perspective. In Shin, J.C., Toutkoushian, R.K., and Teichler, U., (Eds.), University Rankings: Theoretical Basis, Methodology and Impacts on Global Higher Education. Dordrecht: Springer, pp. 229-258.

Arimoto, A. (2013a). Research and teaching: The changing views and activities of the academic profession. In Teichler, U., Arimoto, A., and Cummings, W.K., (Eds.) The changing academic profession: Major findings of a comparative survey. Dordrecht: Springer.

Arimoto, A. (2013b). The teaching and research nexus in the third wave age. In Shin, J.C., Arimoto, A., Cummings, W. and Teichler, U.,(Eds.) Teaching and Research in Contemporary Higher Education: Systems, Activities and Rewards. Pp. 117-163. Dordrecht; Springer.

Arimoto, A., Daizen, T., Kimoto, N., and Huang, H. (2013). Henbousuru Ajia no Daigakukyojushoku [Changing Academic Profession in Asia (2)]. Paper presented to $65^{\text {th }}$ Annual Conference of Japan Society of Educational Sociology, held at Saitama University, 21-22 November, 2013.

Arimoto, A., \& Ehara, T. [Eds.], (1996). Daigakukyojushoku no kokusaihikaku (International Comparison of the Academic Profession). Tokyo: Tamagawa University Press.

Ben-David, J. (1977). Centers of learning. New York: McGraw-Hill.

Boyer, E.L. (1990). Scholarship reconsidered: Priorities of the professoriate. Princeton: Carnegie Foundation for the Advancement of Teaching.

Brubacher, J. \& Rudy, W. (1969). Higher education in transition. New York: Harper and Row.

CCE (Central Council for Education) (2005). Wagakuni no koutou kyoiku no shoraizo (A future vision for higher education in Japan." (Report)

CCE (Central Council for Education) (2008). Gakushikatei no kouchiku nimukete (Towards construction 
of undergraduate education) (Report)

CCE (Central Council for Education) (2012). Aratanamirai wo kizukutame no daigakukyoiku no shitsutekitenkai ni mukete (Toward quality transformation of university education to construct new future. (Report)

Clark, B.R. (1983). Higher education system: Academic organization in cross-national perspective. Berkley: University of California Press.

Clark, B.R. (1995). Places of inquiry: Research and advanced education in modern university. Berkeley: University of California Press.

Cole, S., and Cole, J., (1967). Scientific output and recognition: A study in the operation of the reward system in science, American Sociological Review, Volume 32, Issue3 (Jun., 1967), pp. 377-390.

Halsey, A.H. \& Trow, M. (1971). The British academics. Boston: Harvard University Press.

Light, D.W., Jr. (1974). The structure of the academic professions, Sociology of Education, Vol. 6.

London Times, (2008). QS Quacquarelli Symonds (www.topuniversities.com)

Merton, R.K. (1973). The sociology of science: Theoretical and empirical investigations, edited by N. Storer. Chicago: The University of Chicago Press.

Nicholls, G. (2005). The challenge to scholarship: Rethinking learning, teaching, and research, Key Issues in Higher Education. London: Routledge.

NISTEP (2013). Nippon no daigakuniokeru kenkyuryoku no genjou to kadai (Present situation and problem of research power in Japanese universities). pp. 1-30.

Ross, M.G. (1976). The university: The anatomy of academe, New York: McGraw-Hill.

Shin, J.C., Toutkoushian, R.K., and Teichler, U., (Eds.) (2011). University rankings: Theoretical basis, methodology and Impacts on global higher education. Dordrecht: Springer.

Shin, J.C., Arimoto, A., Cummings, W. and Teichler, U. (Eds.) (2013). Teaching and research in contemporary higher education: Systems, activities and rewards. Dordrecht; Springer.

Shinbori, M. (1973). Gakumontekiseisansei no kenkyu (Research of academic productivity), DaigakuRonshu, No,1, pp. 11-19.Research Institute for Higher Education, Hiroshima University.

Stanford Encyclopedia of Philosophy, 2012. http://plato.stanford.edu/entries/wilhelm-humboldt/

Thomson Leuters, (Ed.) (2010). The world university rankings 2010.

UC (University Council) (1991). Daigakukyoiku no kaikakakunituite (On the reforms of university education) (Report)

Ushiogi, M. (2008). Humboldt rinen no shuen?: Gendaidaigaku no sinjigen (Is the end of Humboldtian ideal?: New dimension of modern university). Tokyo: Toshindo Publishing Co.

Von Humboldt, W. (1910). On the spirit and the organizational framework of intellectual institutions in Berlin, Translated by Edward Shils, Minelva 8 (1970): pp. 242-50. 